\title{
Pengembangan mobile game untuk pembelajaran pada materi larutan penyangga
}

\author{
Sri Yosimayasari, Hartono*, Syarifuddin \\ Magister Teknologi Pendidikan, Fakultas Keguruan dan Ilmu Pendidikan, Universitas Sriwijaya, \\ Jalan Srijaya Negara, Palembang 30139, Indonesia \\ *Coressponding Author. E-mail: hartonosains@yahoo.co.id
}

Received: 9 Januari 2021; Revised: 8 November 2021; Accepted: 10 November 2021

\begin{abstract}
Abstrak: Penelitian ini bertujuan menghasilkan produk mobile game untuk pembelajaran pada materi larutan penyangga yang valid, praktis dan efektif terhadap hasil belajar dan motivasi peserta didik di SMA Bina Mandiri Banyuasin. Penelitian ini menggunakan model pengembangan Alessi \& Trollip yang terdiri dari beberapa tahap yaitu perencanaan, desain dan pengembangan. Mobile game untuk pembelajaran dinyatakan valid setelah melalui proses uji alpha kepada ahli dan diperbaiki sesuai dengan saran ahli. Mobile game untuk pembelajaran dinyatakan praktis setelah melalui tahap uji beta yang dilakukan oleh tiga orang peserta didik yang berkemampuan tinggi, sedang, dan rendah. Mobile game untuk pembelajaran memberikan efek potensial terhadap hasil belajar peserta didik yang dapat diketahui dari rerata n-gain yaitu 0,614 dengan kriteria sedang. Penggunaan mobile game untuk pembelajaran materi larutan penyangga dapat meningkatkan skor motivasi peserta didik pada semua kategori baik itu attention, relevance, confidence dan satisfaction setelah melalui pengambilan data dengan menggunakan angket berdasarkan desain motivasi belajar model ARCS.
\end{abstract}

Kata Kunci: mobile game, penelitian pengembangan, larutan penyangga

\section{Development of mobile game for learning on buffer solution material}

Abstract: This study aims to produce a mobile game product for learning on buffer solution material that is valid, practical and effective on learning outcomes and student motivation at SMA Bina Mandiri Banyuasin. This study uses the Alessi \& Trollip development model which consists of several steps, namely planning, design and development. Mobile games for learning are declared valid after going through the alpha test process to experts and corrected according to expert advice. Mobile games for learning are stated to be practical after going through the beta test stage carried out by three high, medium, and low-ability students. Mobile games for learning have a potential effect on student learning outcomes which can be seen from the $n$-gain mean of 0.614 with moderate criteria. The use of mobile games for learning buffer solution material can increase students' motivation scores in all categories of attention, relevance, confidence and satisfaction after going through data collection using a questionnaire based on the ARCS model of learning motivation design.

Keywords: mobile games, buffer solutions, development research.

How to Cite: Yosimayasari, S., Hartono \& Syarifuddin. (2021). Pengembangan mobile game untuk pembelajaran pada materi larutan penyangga. Jurnal Inovasi Pendidikan IPA, 7(1), 94105. doi: http://dx.doi.org/10.21831/jipi.v7i1.37561

\section{PEENDAHULUAN}

Perkembangan teknologi yang terus maju berdampak pada semua sektor kehidupan manusia termasuk dalam bidang pendidikan (Ayu et al., 2019; Raja \& Nagasubramani, 2018). Kemajuan inovasi teknologi membuat peserta didik terbiasa menggunakan peralatan canggih (Raja \& Nagasubramani, 2018). Hal ini menjadi salah satu faktor yang menyebabkan peserta didik akan merasa bosan dalam proses pembelajaran yang biasa dan tidak memanfaatkan teknologi (Aksari et al., 2017). Fenomena ini terjadi pada mata pelajaran kimia yang dianggap sulit dan membosankan oleh sebagian besar peserta didik (Kousa et al., 2018; Ratnasari \& Setiawan, 2018). 


\section{Jurnal Inovasi Pendidikan IPA, 7 (1), 2021 - 95}

Sri Yosimayasari, Hartono, Syarifuddin

Kimia adalah salah satu mata pelajaran yang sulit dipelajari (Srisawasdi \& Panjaburee, 2019; Treagust et al., 2018).Fenomena tersebut terjadi karena materi kimia cenderung bersifat analitis bahkan ada beberapa materi yang abstrak dan tidak dapat diamati secara langsung dengan panca indra (Ristiyani \& Bahriah, 2016). Selain itu kimia dianggap sebagai pelajaran yang sulit karena kosa katanya yang khas, terdapat banyak rumus, teori, hafalan dan juga perhitungan (Andromeda et al., 2016). Ada beberapa materi pembelajaran kimia yang dianggap sulit untuk dipelajari oleh peserta didik, salah satunya adalah materi larutan penyangga (Setiawan \& Kusumo, 2019).

Larutan penyangga merupakan materi yang sifatnya kompleks dan terdapat submateri yang menggunakan perhitungan dalam menyelesaikan soal-soalnya (Ratnasari \& Setiawan, 2018). Kesulitan dalam mempelajari materi larutan penyangga di SMA Bina Mandiri terbukti dari data hasil belajar peserta didik yang rendah yaitu $72,4 \%$ berada dibawah standar ketuntasan minimal.

Kesulitan belajar ini diperparah dengan terjadinya pandemi COVID-19 yang berpengaruh terhadap aspek pendidikan (Setiaji \& Dinata, 2020). Fenomena pandemi COVID-19 mengharuskan setiap elemen pendidikan untuk tetap melakukan proses pembelajaran secara daring dan berkelanjutan selama pandemi berlangsung (Herliandry et al., 2020). Salah satu perangkat yang banyak digunakan dan populer di dunia pendidikan adalah komputer (Nugraha et al., 2020). Peserta didik di SMA Bina Mandiri sudah terbiasa menggunakan komputer karena dan semuanya memiliki smartphone sehingga pembelajaran secara daring masih dapat terlaksana. Namun, tetap saja pemanfaatan teknologi ini membutuhkan adaptasi.

Berdasarkan hasil wawancara yang telah dilakukan dengan beberapa peserta didik SMA Bina Mandiri terdapat beberapa kesulitan dalam memahami pembelajaran kimia secara daring, terutama dalam materi yang memiliki unsur hitungan yang harus mengaplikasikan rumus. Selain itu, beberapa peserta didik mengalami kendala dengan paket data dan koneksi internet sehingga kesulitan dalam mengikuti pembelajaran melalui aplikasi teleconference. Oleh karena itu pendidik hanya dapat memberikan video tutorial menjawab soal dan hanya sesekali menggunakan teleconference. Kegiatan pembelajaran yang seperti ini menyebabkan peserta didik mengalami kejenuhan dalam belajar karena biasanya pada pertemuan tatap muka pendidik memberikan games secara berkelompok ataupun ice breaking di tengah pembelajaran yang membuat peserta didik kembali antusias untuk belajar.

Konsekuensi dari pandemi ini membuat perlu adanya peningkatan keterampilan digital pada setiap elemen pendidikan yang sejalan dengan tren dan realitas global yang muncul dengan memanfaatkan dan mengintegrasikan teknologi informasi yang ada (Onyema et al., 2020). Hal ini dilakukan supaya pembelajaran dapat terlaksana dengan baik dan memberikan hasil yang baik pula pada peserta didik.

Masalah utama dalam mengintegrasikan teknologi informasi pendidikan saat ini adalah merancang kegiatan pengajaran untuk pembelajaran digital dan menerapkan alat teknologi secara fleksibel (Lin et al., 2017).Salah satu cara yang dapat dilakukan untuk mengintegrasikan pembelajaran dengan teknologi yang menarik, menyenangkan, fleksibel dan lebih mudah diterima peserta didik adalah dengan menggunakan games dalam proses pembelajaran (Cahyana et al., 2017)

Pembelajaran yang terintegrasi dengan games dapat meningkatkan kemampuan siswa baik itu motivasi belajar (Perini et al., 2018), prestasi (C. H. Su \& Cheng, 2015), dan kepuasan yang merupakan tren masa depan untuk pendidikan (Huang et al., 2017; Lay, A. \& Osman, 2018). Game based learning (GBL) merupakan permainan edukasi digital yang terintegrasi dengan pembelajaran untuk membantu pengguna mempelajari mata pelajaran tertentu (Chang et al., 2017). GBL adalah proses pembelajaran yang memanfaatkan aplikasi game edukasi dengan tujuan untuk efektifitas pembelajaran (Huang et al., 2017).

Penelitian pengembangan mobile game untuk pembelajaran telah dilakukan pada berbagai tingkatan pendidikan dan berbagai bidang studi seperti ditingkat universitas (Wang et al., 2011) pada bidang sains (Jones., 2018) bahasa (Huang et al., 2017). Penelitian di sekolah menengah atas pada mata pelajaran kimia (Cahyana et al., 2017), akuntansi (Saputri et al., 2020). Penelitian di sekolah menengah pertama (Huizenga et al., 2019; Lay, A. \& Osman, 2018) pada mata pelajaran sejarah (Huizenga, 2009). Penelitian di sekolah dasar (C.-H. Su \& Cheng, 2013; C. H. Su \& Cheng, 2015).

Beberapa penelitian tersebut menunjukkan bahwa media MGBL dapat digunakan dalam proses pembelajaran pada berbagai bidang ilmu pengetahuan. Media ini dapat dikemas menjadi media yang menyenangkan dan dapat digunakan secara fleksible sehingga bisa dimanfaatkan peserta didik pada kegiatan pembelajaran dalam segala situasi baik dalam kondisi tatap muka maupun dalam kondisi tatap 


\section{Jurnal Inovasi Pendidikan IPA, 7 (1), 2021 - 96}

Sri Yosimayasari, Hartono, Syarifuddin

maya. Oleh sebab itu, peneliti mengembangkan mobile game untuk pembelajaran pada materi larutan penyangga yang valid, praktis dan dapat mengetahui efek potensialnya.

\section{METODE}

Penelitian ini menggunakan rancangan penelitian pengembangan (development research). Penelitian pengembangan adalah penelitian yang mengarah pada penghasilan produk, desain dan proses dimana hasil penelitian tersebut divalidasi dengan kriteria tertentu (Richey, 1994; Setyosari, 2013). Penelitian pengembangan ini menghasilkan produk berupa mobile game materi larutan penyangga..

Penelitian dilaksanakan pada semester genap tahun ajaran 2019/2020 dan dilakukan di SMA Bina Mandiri Banyuasin. Penelitian ini melibatkan peserta didik kelas XI IPA sebagai subjek penelitian. Subjek pada tahap uji beta adalah 3 peserta didik dan pada tahap uji coba produk sebanyak satu kelas yang jumlahnya 32 peserta didik. Peneliti menggunakan model pengembangan produk Alessi dan Trollip (2001) dengan tiga tahapan utama yaitu planning, design dan development. Desain pengembangan mobile game menggunakan model pengembangan Alessi dan Trollip terdapat dalam Gambar 1.

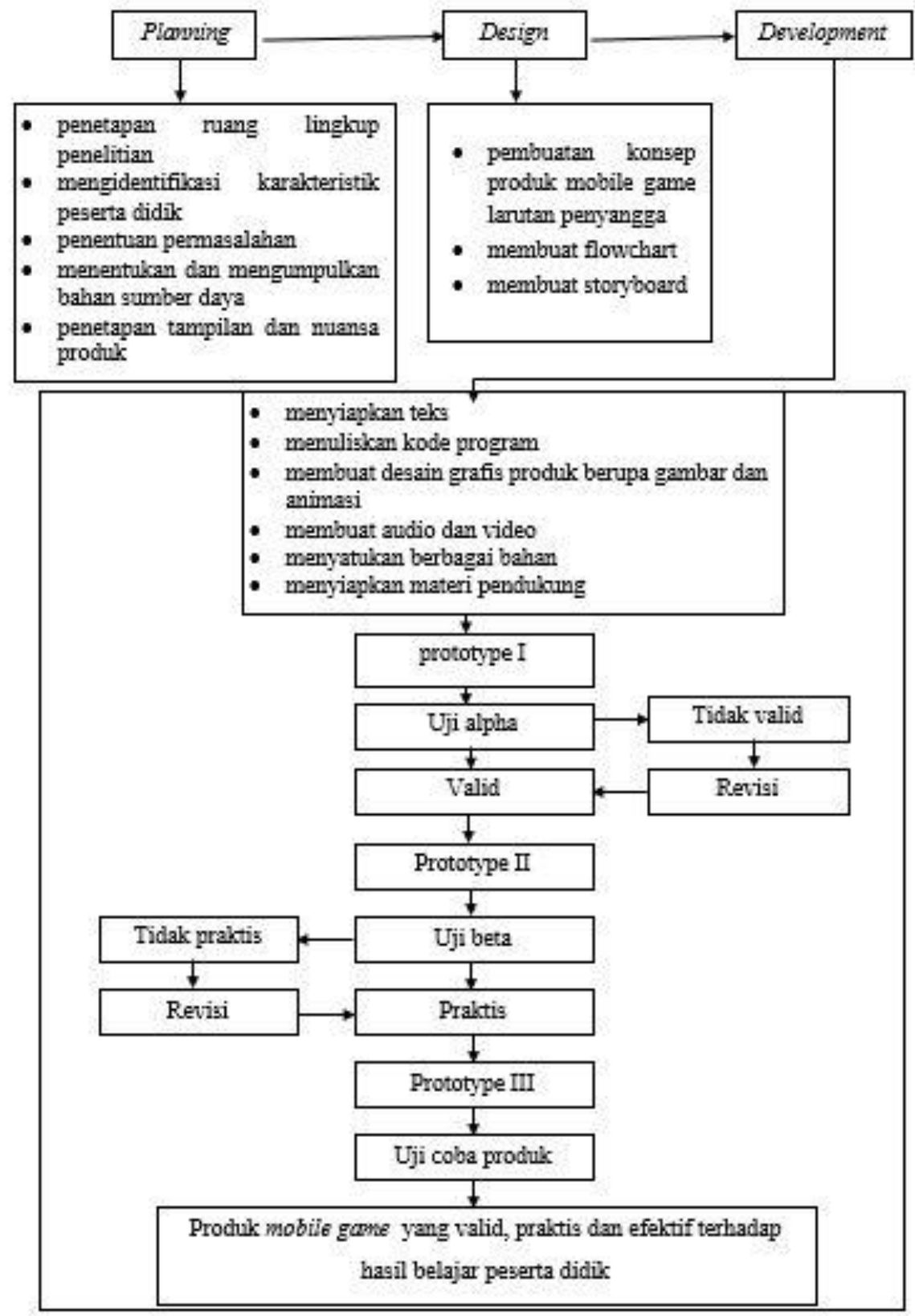

Gambar 1. Prosedur pengembangan modifikasi Model Allesi \& Trollip 


\section{Jurnal Inovasi Pendidikan IPA, 7 (1), 2021 - 97}

Sri Yosimayasari, Hartono, Syarifuddin

Instrumen pengumpulan data yang digunakan dalam penelitian ini adalah wawancara, angket dan tes. Uji alpha dilakukan untuk mengetahui validitas dari produk yang telah dikembangkan. Data Hasil angket pada uji alpha adalah data kualitatif yang berbentuk saran dan komentar dari ahli yang akan menjadi panduan untuk peneliti memperbaiki mobile game yang telah dikembangkan. Uji beta dilakukan untuk mengetahui prakatikalitas produk. uji ini dilakukan oleh 3 peserta didik yang memiliki kemampuan tinggi, sedang dan rendah. praktikalitas diketahui berdasarkan cheklist praktis pada angket dan respon positif dari peserta didik.

Efektivitas dari produk mobile game dapat diketahui dari tujuan pembelajaran yang dicapai yang terlihat dari hasil belajar. Uji ini dilakukan sebelum pembelajaran (pretest) dengan tujuan ntuk mengetahui pengetahuan awal siswa dan setelah pembelajaran (posttest) yang bertujuan untuk mengetahui kemampuan peserta didik setelah menggunakan mobile game.Uji yang dilakukan berbentuk soal pilihan ganda. Peningkatan hasil belajar peserta didik digunakan untuk mengetahui efek potensial produk melalui perhitungan normalisasi gain (n-gain). Hasil n-gain terbagi menjadi 3 kategori yaitu, jika Ngain $\leq 0,3$ maka kategori rendah, jika $0,7 \geq$ Ngain $\geq 0,3$ maka kategori sedang dan jika N-gain $\geq 0,7$ Tinggi maka termasuk pada kategori tinggi.

Motivasi peserta didik pada penelitian ini diketahui melaui angket berdasarkan John Keller's ARCS learning motivation design (Keller, 2010). Arcs adalah akronim dari attention, relevance, confidence and satisfaction. Angket motivasi diberikan sebelum dan sesudah pembelajaran menggunakan produk. Penilaian ini menggunakan skala likert dengan rentang 1 sampai 5. Angket dapat dinilai untuk masing-masing dari empat subskala dan skor skala total.

Pada analisa data motivasi belajar, tidak dapat ditetapkan kategori sebagai tingkat motivasi tinggi atau rendah karena tidak ada norma untuk angket. Namun skor sebelum penggunaan media dapat dibandingkan dengan skor setelah penggunaan. Karena ini adalah ukuran khusus situasi, tidak ada ekspektasi untuk distribusi respon yang normal (Keller, 2010).

\section{HASIL DAN PEMBAHASAN}

\section{Tahap Perencanaan}

Pada tahap ini penelitian telah melakukan penetapan ruang lingkup penelitian, mengidentifikasi karakteristik peserta didik, penentuan permasalahan, menentukan dan mengumpulkan bahan sumber daya serta penetapan tampilan dan nuansa produk. Penelitian ini diharapkan dapat mengatasi kesulitan belajar dan meningkatkan motivasi belajar peserta didik di SMA Bina Mandiri khususnya pada pelajaran kimia.

Sebagian besar peserta didik kurang termotivasi dan sulit untuk memahami pelajaran kimia terutama pada materi larutan penyangga. Hal ini dikarenakan pada materi larutan penyangga terdapat konsep abstrak dan juga perhitungan didalamnya. Fenomena ini terlihat dari nilai hasil pembelajaran peserta didik yang sebagian besar masih dibawah Kriteria ketuntasan minimal. Materi larutan penyangga berada pada Kompetensi Dasar 3.12 Menjelaskan prinsip kerja, perhitungan pH, dan peran larutan penyangga dalam tubuh makhluk hidup. Peserta didik mengalami kesulitan dalam mempelajari materi larutan penyangga karena terdapat konsep yang abstrak dan juga perhitungan.

Pandemi covid-19 yang sedang terjadi menambah kesulitan peserta didik untuk memahami materi karena pembelajaran dilakukan secara daring sehingga mereka tidak bisa mendapatkan pembelajaran langsung dari guru. Pembelajaran daring ini menyebabkan peserta didik merasa bosan dan cenderung lebih tertarik menggunakan smartphonenya untuk bermain games atau media sosial.

Media pembelajaran yang menarik dan menyenangkan pada materi larutan penyangga kurang tersedia, padahal peserta didik memiliki sarana dan prasarana yang memadai. Seperti tersedianya laptop atau smartphone dan juga kuota internet bahkan ada beberapa peserta didik yang memiliki fasilitas wifi dirumahnya. Oleh sebab itu, dibutuhkan media pembelajaran yang menarik dan menyenangkan berupa mobile game materi larutan penyangga. Tampilan pada produk direncanakan berbentuk game petualangan. Pengguna mobile game berusaha untuk memenangkan permainan dengan melewati berbagai rintangan. Produk ini dapat diaplikasikan pada komputer dan juga di smartphone.

\section{Tahap Desain}

Tahap desain dilakukan dengan melakukan pembuatan konsep produk mobile game larutan penyangga, membuat flowchart dan storyboard . Produk ini di desain memiliki lima menu utama berupa 


\section{Jurnal Inovasi Pendidikan IPA, 7 (1), 2021 - 98}

Sri Yosimayasari, Hartono, Syarifuddin

menu kompetensi, menu indikator \& tujuan, menu materi, menu game dan menu profil. Menu kompetensi berisi kompetensi inti dan kompetensi dasar dari larutan penyangga. Menu indikator \& tujuan berisi indikator pencapaian kompetensi dan tujuan pembelajaran. Menu materi berisikan materi larutan penyangga yang dibagi menjadi empat bagian yaitu definisi dan komponen larutan penyangga, mekanisme dan pembuatan larutan penyangga, perhitungan $\mathrm{pH}$ larutan penyangga dan peranan larutan penyangga dalam tubuh.

Menu game berisikan game larutan penyangga yang terdiri dari tiga tingkatan level. Pada setiap level peserta didik harus mengumpulkan erlenmeyer ungu untuk memenangkan pertandingan. Namun untuk memperoleh erlenmeyer ungu peserta didik harus melewati rintangan berupa monster dan menjawab pertanyaan-pertanyaan yang akan keluar saat perjalanan. Peserta didik dapat mencari jawaban dari setiap pertanyaan dengan membaca ringkasan materi ataupun video yang ditampilkan saat karakter menyentuh bendera yang disebarkan pada berbagai tempat pada game. Sedangkan Menu profil berisi data singkat dari pengembang produk.

Flowchart dibuat berdasarkan alur proses penggunaan mobile game larutan penyangga. Gambar flowchart mobile game larutan penyangga dapat dilihat pada Gambar 2, Gambar 3, dan Gambar 4.

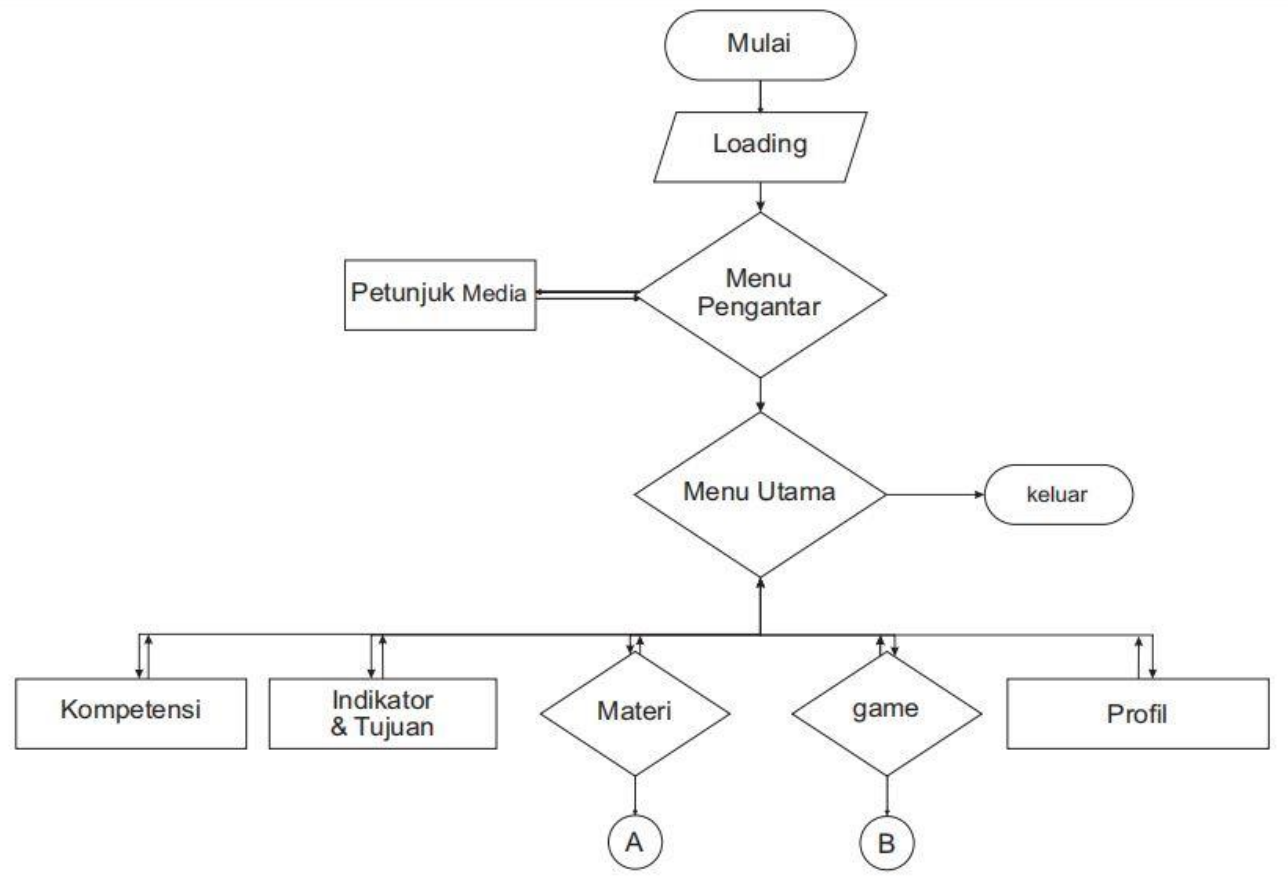

Gambar 2. Flowchart halaman utama

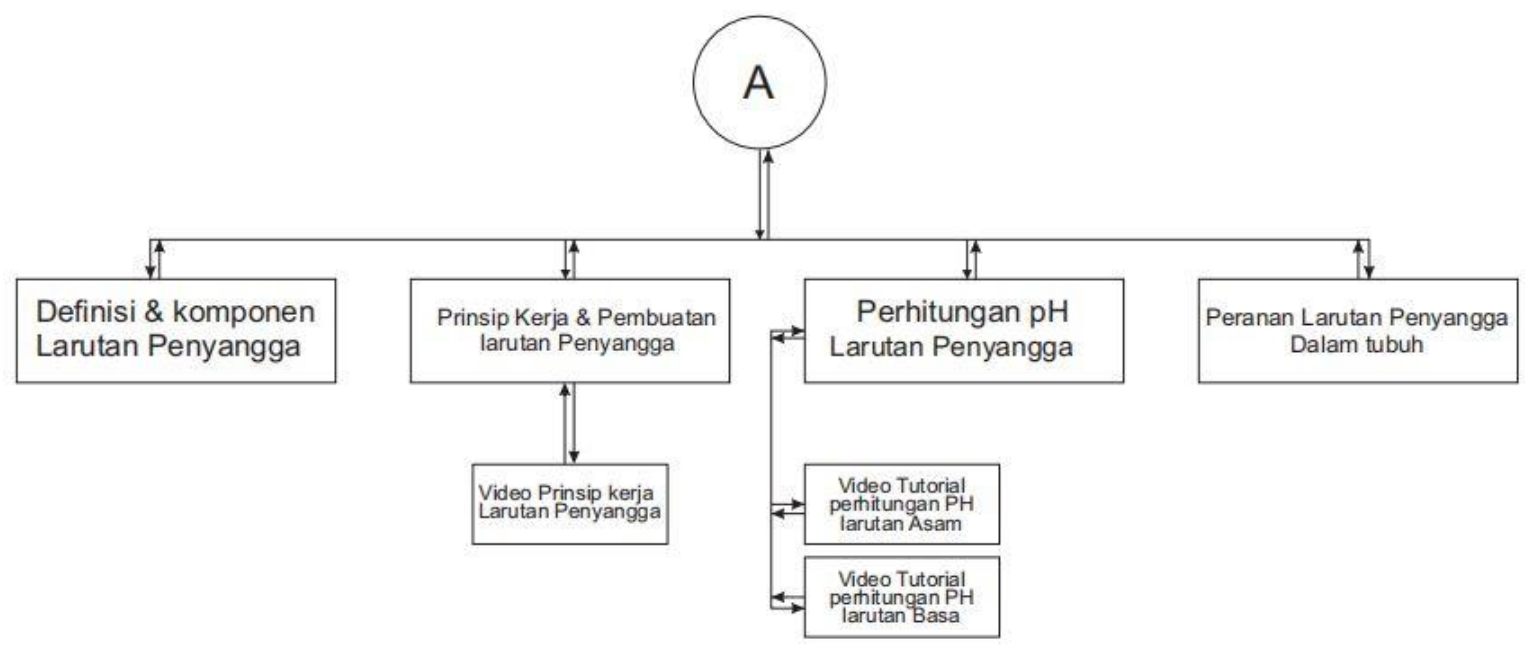

Gambar 3. Flowchart halaman materi 
Jurnal Inovasi Pendidikan IPA, 7 (1), 2021 - 99

Sri Yosimayasari, Hartono, Syarifuddin

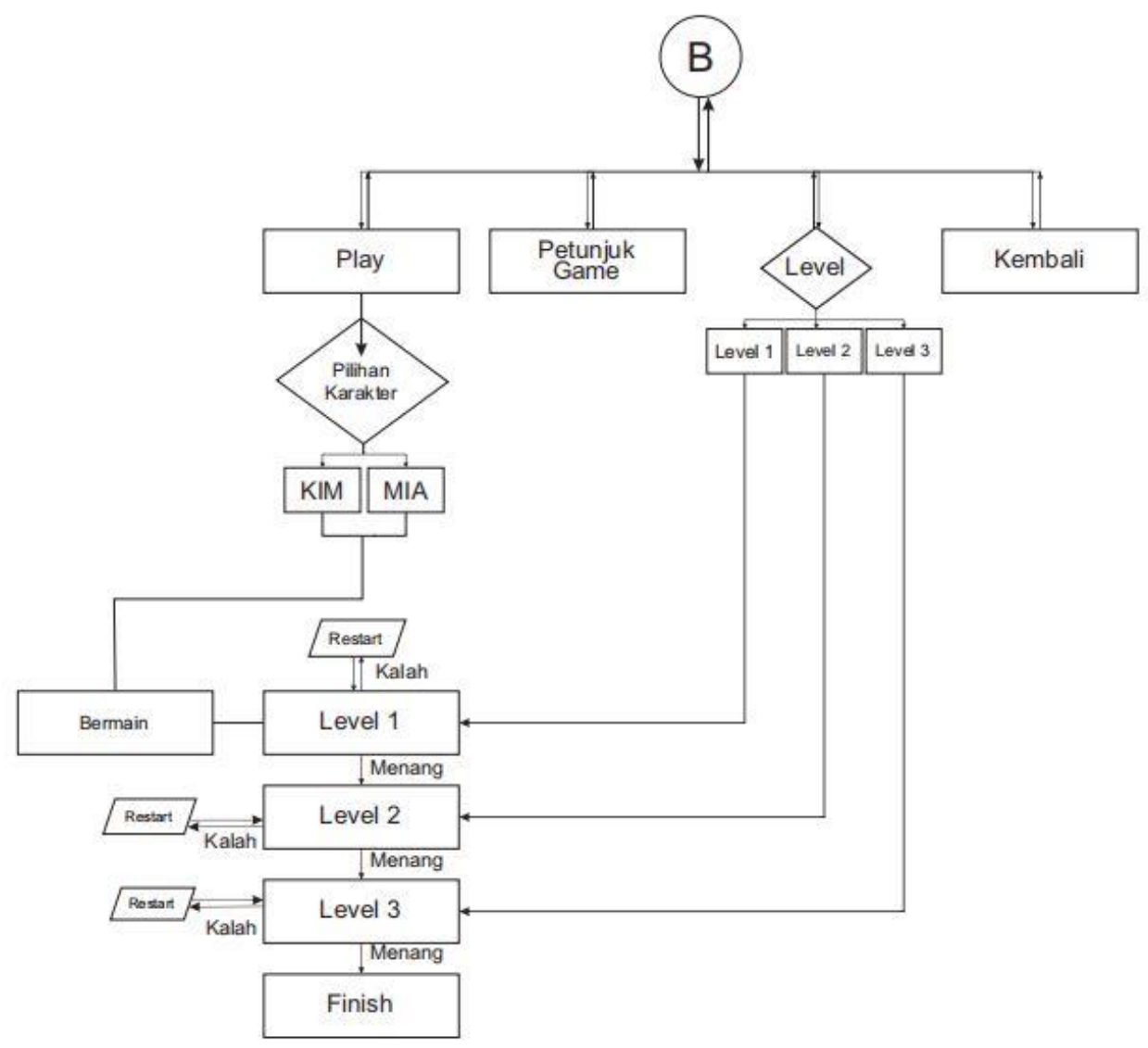

Gambar 4. Flowchart halaman game

Storyboard memberikan representasi visual dari desain produk mobile game secara detail yang akan diterapkan di produk. Baik itu berupa tampilan, teks, gambar, video, suara dan juga keterangannya.

\section{Pengembangan}

Pada tahap ini langkah pertama adalah menyiapkan teks materi larutan penyangga untuk menu materi dan pop-up berisi rangkuman materi yang akan muncul pada saat game berlangsung. Semua teks disajikan dalam bentuk gambar menggunakan Adobe Ilustrator. Langkah selanjutnya yaitu menuliskan kode program, persiapan desain grafis produk berupa gambar dan animasi, membuat audio dan video menggunakan aplikasi explaindio dan wondershare filmora, menyatukan berbagai bahan dalam aplikasi construct 2, melakukan uji alpha lalu revisi, melakukan uji beta lalu revisi kemudian melakukan uji coba produk. Tampilan produk yang telah dikembangkan dapat dilihat pada Gambar 5.

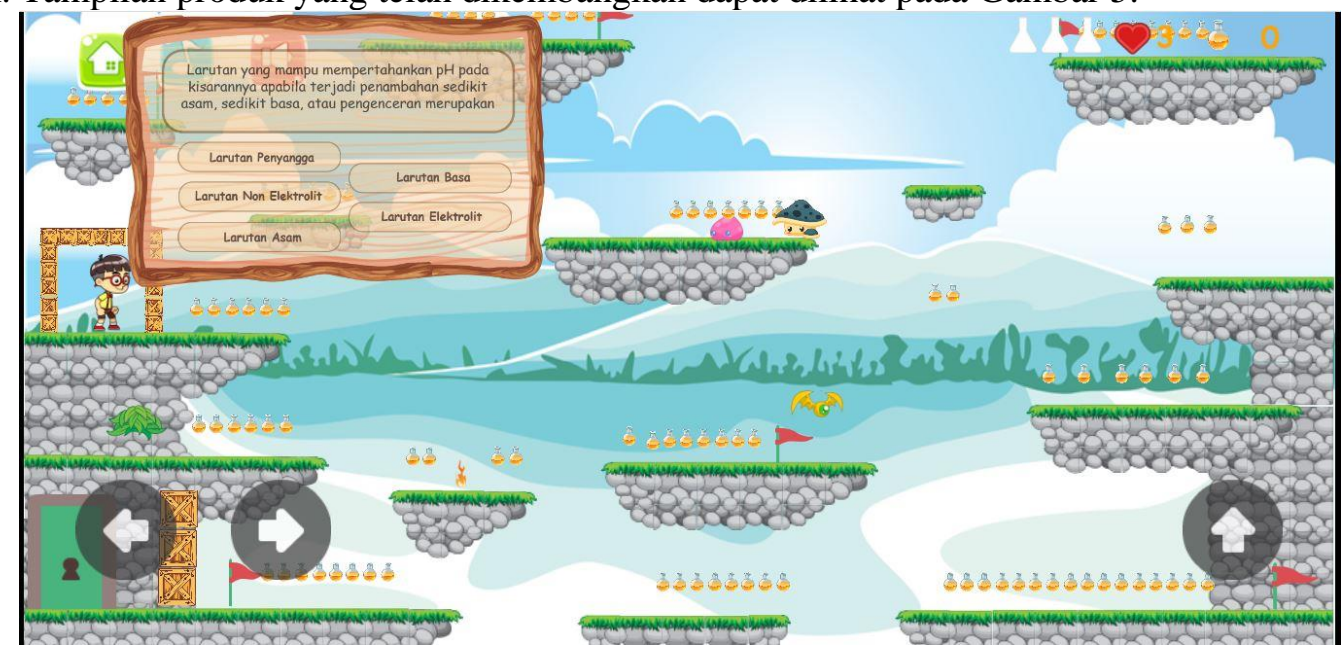

Gambar 5. Tampilan game pada produk 


\section{Jurnal Inovasi Pendidikan IPA, 7 (1), 2021 - 100}

Sri Yosimayasari, Hartono, Syarifuddin

Produk mobile game dinyatakan valid setelah melalui uji alpha yang dilakukan oleh tiga orang ahli. Setiap ahli memvalidasi produk berdasarkan item pernyataan pada angket. Terdapat 37 item pernyataan disertai dengan kolom keterangan dapat diterima, perlu tindak lanjut dan juga komentar yang diisi oleh ahli. Peneliti melakukan perbaikan pada item pernyataan yang masih perlu tindak lanjut sesuai dengan komentar dan saran dari Ahli. Rekapitulasi saran dari ahli dan perbaikan yang dilakukan dapat dilihat pada Tabel 1.

Tabel 1. Saran Ahli Dan Perbaikan

\begin{tabular}{|c|c|c|}
\hline Ahli & Saran & Perbaikan \\
\hline Pertama & $\begin{array}{l}\text { Tambahkan video dan animasi } \\
\text { pada menu materi }\end{array}$ & $\begin{array}{l}\text { Penambahan tiga video yaitu dua } \\
\text { video tutorial menjawab soal serta } \\
\text { satu video animasi mekanisme } \\
\text { larutan penyangga dalam } \\
\text { mempertahankan pH }\end{array}$ \\
\hline Kedua & $\begin{array}{l}\text { Perbesar kotak jawaban letakkan } \\
\text { kotak jawaban pada sisi yang tidak } \\
\text { menghalangi tindakan user } \\
\text { selanjutnya untuk mengerakan } \\
\text { avatar, ukuran tulisan terlalu kecil, } \\
\text { aplikasi kurang responsif dan } \\
\text { loading terlalu lama kadang harus } \\
\text { exit dulu (mungkin aplikasinya } \\
\text { terlalu besar). }\end{array}$ & $\begin{array}{l}\text { Memperbesar kotak jawaban dan } \\
\text { meletakkannya ditempat yang } \\
\text { tidak menghalangi pemain ke } \\
\text { langkah selanjutnya, memperbesar } \\
\text { ukuran tulisan dan mempublish } \\
\text { produk di website sehingga produk } \\
\text { dapat digunakan tanpa harus } \\
\text { mendownload aplikasi yang besar. }\end{array}$ \\
\hline Ketiga & $\begin{array}{l}\text { Tambahkan deskripsi pengantar } \\
\text { awalan produk dan petunjuk } \\
\text { penggunaan media }\end{array}$ & Perbaikan sesuai saran ahli \\
\hline
\end{tabular}

Pada uji beta peserta didik diberikan instrumen praktikalitas yang berisikan 12 pernyataan mengenai media yaitu tentang tampilan, mode presentasi, kualitas teks, gambar, audio, video, masukan, spasi, bahasa, istilah \& jargon, pengantar dan arah. Data yang didapatkan dari angket tersebut yaitu hampir semua item di centang praktis oleh peserta didik. Hanya ada satu item yang perlu diperbaiki. Berikut ini adalah komentar dan saran peserta didik pada lembar praktisasi uji beta. Penjelasan lebih lanjut terdapat dalam Tabel 2.

Tabel 2. Komentar Dan Saran Pada Uji Beta

\begin{tabular}{|c|c|c|}
\hline No & Inisial Peserta didik & Komentar dan saran \\
\hline 1. & MAP & $\begin{array}{l}\text { Menurut saya mobile game untuk pembelajaran kimia ini sudah baik karena } \\
\text { sangat menyenangkan dan seru, kita bisa bermain sambil belajar tentang kimia. } \\
\text { Tapi video tutorial menjawab soalnya kecepetan, kalau diperlambat akan lebih } \\
\text { baik. }\end{array}$ \\
\hline 2. & $\mathrm{DM}$ & $\begin{array}{l}\text { Menurut saya mobile game pembelajaran kimia ini sudah sangat baik dan saya } \\
\text { sebagai siswa yang menggunakan mobile game ini sangat suka karena seru, bisa } \\
\text { mengurangi kebosanan mengerjakan tugas daring dirumah. }\end{array}$ \\
\hline 3. & NRU & $\begin{array}{l}\text { Game nya sangat menarik karena terdapat deskripsi tentang materi baik berupa } \\
\text { teks maupun berupa video, lebih mudah untuk memahami materi dan bahasanya } \\
\text { mudah dipahami. }\end{array}$ \\
\hline
\end{tabular}

Revisi dilakukan pada produk sesuai dengan saran yang telah diterima yaitu memperlambat video tutorial menjawab soal perhitungan materi larutan penyangga. Berdasarkan berbagai tanggapan positif dan juga perbaikan yang telah dilakukan terhadap produk dapat disimpulkan bahwa media mobile game larutan penyangga dinyatakan praktis.

Setelah melakukan uji alpha dan uji beta tahap selanjutnya yaitu melakukan uji coba produk. Uji coba produk adalah proses menguji apakah media ini memenuhi tujuannya di lingkungan belajar sebenarnya (Alessi \& Trollip, 2001). Proses uji dilakukan secara daring menggunakan aplikasi zoom meeting. Dokumentasi uji coba produk dapat dilihat pada Gambar 6. 


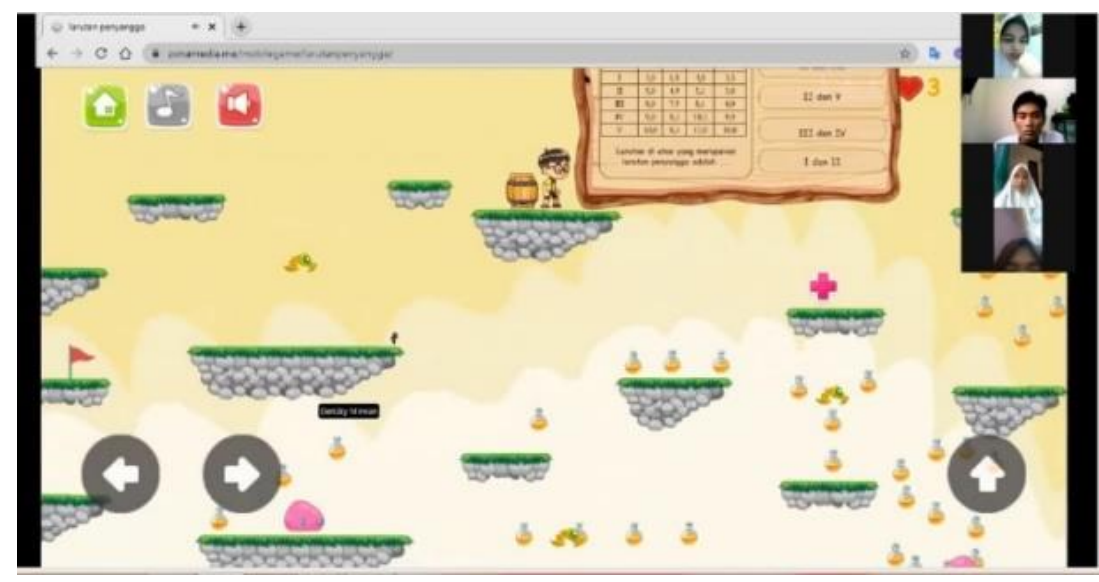

Gambar 6. Peserta Didik Melakukan Sharescreen

Pada uji coba produk didapatkan data skor pretest, skor posttest dan data motivasi belajar peserta didik. Soal pretest dan posttest yang diberikan berupa pilihan ganda berjumlah 20 soal. Rekapitulasi hasil pretest dan posttest dapat dilihat pada Tabel 3 berikut.

Tabel 3. Rekapitulasi Hasil Pretest Dan Posttest.

\begin{tabular}{|c|c|c|c|c|c|c|}
\hline \multirow{2}{*}{ Interval Nilai } & \multicolumn{2}{|c|}{ Jumlah peserta didik } & \multicolumn{2}{|c|}{ Persentase (\%) } & \multirow{2}{*}{ Predikat } & \multirow{2}{*}{ Keterangan } \\
\hline & Pretest & Posttest & Pretest & Posttest & & \\
\hline $89-100$ & 0 & 7 & 0 & 21.875 & $\mathrm{~A}$ & Sangat Baik \\
\hline $77-88$ & 2 & 10 & 6,25 & 31.25 & $\mathrm{~B}$ & Baik \\
\hline $65-76$ & 3 & 11 & 9,375 & 34.375 & $\mathrm{C}$ & Cukup \\
\hline $64-0$ & 27 & 4 & 84,37 & 12.5 & $\mathrm{D}$ & Kurang \\
\hline
\end{tabular}

Kriteria ketuntasan minimal (KKM) mata pelajaran kimia kelas XI IPA di SMA Bina Mandiri adalah 65. Berdasarkan hasil rekapitulasi pretest pada Tabel 3, diketahui terdapat lima peserta didik yang mendapatkan nilai di atas KKM dengan interval 65-76 dan 77-88. Peserta didik yang mendapatkan nilai dibawah KKM sebanyak 27 orang dengan interval 64-0.

Berdasarkan Tabel 3 dapat diketahui ada tujuh peserta didik yang mendapatkan skor dengan predikat sangat baik dengan interval 89-100 pada saat posttest. Terdapat sepuluh peserta didik yang memiliki skor dengan kategori baik pada interval 78-88. Sebelas peserta didik mendapatkan skor dengan kategori cukup pada interval 65-76. Hanya ada empat peserta didik yang belum memenuhi KKM dengan kategori nilai cukup pada interval 64-0.

Berlandaskan beberapa data yang telah didapatkan dari pretest dan posttest, dapat diketahui terjadi peningkatan kemampuan peserta didik setelah menggunakan mobile game larutan penyangga. Peningkatan tersebut digambarkan pada diagram berikut.

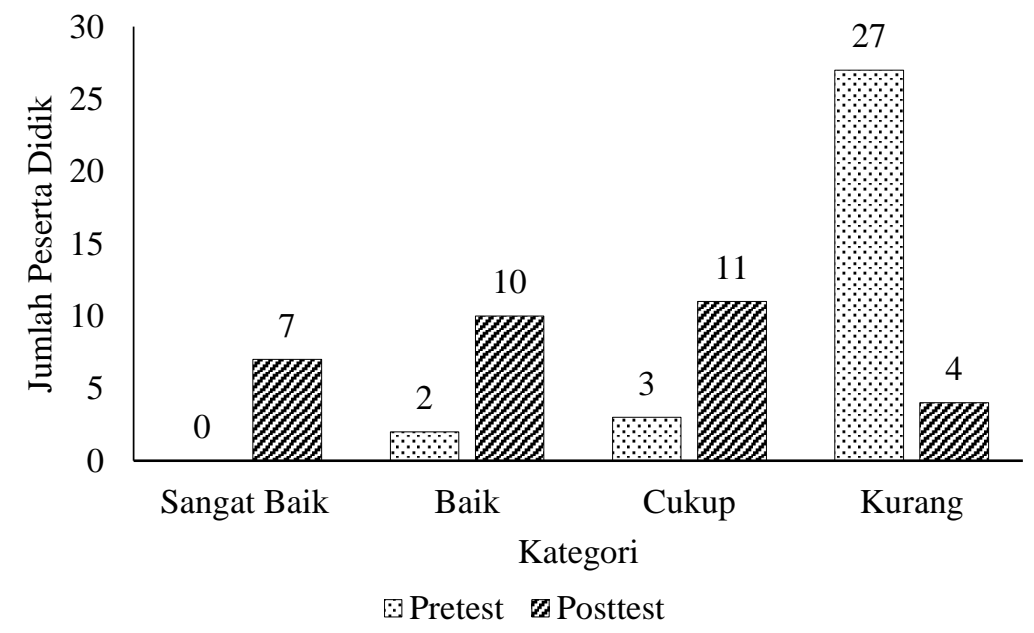

Gambar 7. Diagram Perbandingan Hasil Pretest Dan Posttest 


\section{Jurnal Inovasi Pendidikan IPA, 7 (1), 2021 - 102}

Sri Yosimayasari, Hartono, Syarifuddin

Diagram tersebut menunjukkan kenaikan jumlah peserta didik yang mengalami peningkatan kemampuan setelah menggunakan media. Hasil pretest menunjukkan 27 peserta didik masuk dalam kategori kurang artinya memiliki skor dibawah KKM. Hanya 5 siswa yang mampu melewati KKM dan masuk dalam kategori baik dan cukup. Peningkatan yang signifikan terjadi setelah penggunaan produk yang ditunjukkan dengan hasil posttest. Sebanyak 28 peserta didik mendapatkan skor $\geq 65$ yang artinya skor mereka dapat mencapai ataupun melampaui KKM. Hasil posttest menunjukkan 7 peserta didik mendapat predikat sangat baik, 10 peserta didik berpredikat baik dan 11 peserta didik berpredikat cukup.

Efektivitas terhadap hasil belajar didapatkan dari analisa rata-rata pretest dan posttest yang kemudian dihitung menggunakan rumus $\mathrm{N}$-gain. Skor rata-rata pretest dan posttest dapat dilihat pada Tabel 4.

Tabel 4. Rekapitulasi Rata-Rata Pretest, Posttest Dan N-Gain

\begin{tabular}{|c|c|c|c|c|c|}
\hline Rerata Pretest & Rerata Posttest & \multicolumn{3}{|c|}{ Persentase $n$-gain peserta didik (\%) } & $\begin{array}{l}\text { Rerata } \\
N \text {-gain }\end{array}$ \\
\hline 38,125 & gori 76,25 & $\begin{array}{c}25 \\
\text { Tinggi }\end{array}$ & $\begin{array}{c}68,75 \\
\text { Sedang }\end{array}$ & $\begin{array}{c}6,25 \\
\text { Rendah }\end{array}$ & $\begin{array}{c}0.614 \\
\text { sedang }\end{array}$ \\
\hline
\end{tabular}

Skor rerata $N$-gain yang dihasil adalah 0,614 . Hasil ini menunjukkan skor $0,7>\mathrm{g} \geq 0,3$ artinya pengembangan produk ini masuk kedalam kategori sedang (Hake, 2002). Berdasarkan hasil tersebut dapat diketahui penggunaan mobile game larutan penyangga memberikan pengaruh yang cukup besar dalam peningkatan hasil belajar peserta didik.

Hasil belajar yang didapatkan setiap peserta didik berbeda-beda. Peningkatan yang paling tinggi setelah melakukan pretest dan posttest dialami oleh peserta didik dengan inisial An dan RN yaitu 80 dan 75 poin. Peningkatan yang cukup tinggi ini dikarenakan peserta didik bertempat tinggal di daerah yang memiliki koneksi internet yang sangat baik sehingga produk mobile game larutan penyangga dapat digunakan secara maksimal. Selain itu kedua peserta didik termasuk dalam kategori yang memiliki kemampuan tinggi, sehingga ketika mempelajari sesuatu hal yang baru dengan fasilitas atau media yang dapat diakses dengan baik maka akan memberikan hasil yang baik juga pada hasil belajarnya.

Peserta didik yang berinisial An, AH, ME, RN dan SN mendapatkan nilai posttest yang paling tinggi yaitu 95 poin. Kelima peserta didik bertempat tinggal di daerah yang dapat mengakses internet dengan sangat baik, bahkan ada beberapa dari mereka yang memiliki fasilitas wifi dirumahnya sehingga dapat leluasa dan maksimal dalam menggunakan produk. Peserta didik yang berinisial AH merupakan peserta didik yang menyukai game online, sehingga ketika menggunakan mobile game larutan penyangga untuk belajar ia sangat antusias. Selain itu AH termasuk dalam golongan peserta didik yang berkemampuan tinggi. ME dan SN juga merupakan peserta didik yang berkemampuan tinggi, bahkan pada saat pretest mereka mendapatkan nilai di atas KKM. Hal tersebut dikarenakan ME dan SN telah mempelajari materi mengenai larutan penyangga di bimbingan belajar sehingga mereka telah memiliki pengetahuan awal yang lebih mengenai larutan penyangga dibandingkan dengan teman sekelasnya.

Ada empat peserta didik yang mendapatkan hasil posttest dengan kategori rendah (tidak mencapai atapun melampaui KKM). Peserta didik tersebut berinisial ANF, JS, MK dan MRA. Keempat peserta didik bertempat tinggal di daerah yang sulit untuk mendapatkan koneksi internet sehingga tidak dapat menggunakan produk dan menjawab soal dengan maksimal. Selain itu, keempat peserta didik masuk kedalam kategori berkemampuan rendah sehingga cukup sulit bagi peserta didik untuk menjawab pertanyaan dengan benar.

Pengambilan data angket motivasi belajar diambil pada pertemuan pertama sebelum menggunakan media dan pertemuan terakhir setelah menggunakan media. Terdapat 36 item pernyataan yang terdiri dari pernyataan postif dan negatif. Tabel 5 menunjukkan skor motivasi peserta didik berdasarkan kategori sebelum dan sesudah penggunaan produk.

Tabel 5. Rekapitulasi Skor Motivasi Peserta Didik

\begin{tabular}{lcl}
\hline Kategori ARCS & $\begin{array}{c}\text { Skor sebelum } \\
\text { penggunaan media }\end{array}$ & $\begin{array}{c}\text { Skor setelah } \\
\text { penggunaan media }\end{array}$ \\
\hline Attention & 2.91 & 4.09 \\
Relevance & 3.09 & 3.99 \\
Confidence & 2.80 & 3.83 \\
Satisfaction & 2.83 & 3.96 \\
\hline
\end{tabular}




\section{Jurnal Inovasi Pendidikan IPA, 7 (1), 2021 - 103}

Sri Yosimayasari, Hartono, Syarifuddin

Berdasarkan Tabel dapat diketahui bahwa terjadi peningkatan skor motivasi pada setiap kategori ARCS. Pada kategori attention terjadi peningkatan skor yang semula 2.91 menjadi 4.09. Kategori relevance mengalami peningkatan dari 3.09 menjadi 3.99. Confidence peserta didik mengalami kenaikan skor yaitu 2.80 menjadi 3.83 dan satisfaction meningkat dari 2.83 menjadi 3.96. Berikut ini Diagram perbandingan skor peningkatan motivasi peserta didik sebelum dan setelah penggunaan produk.

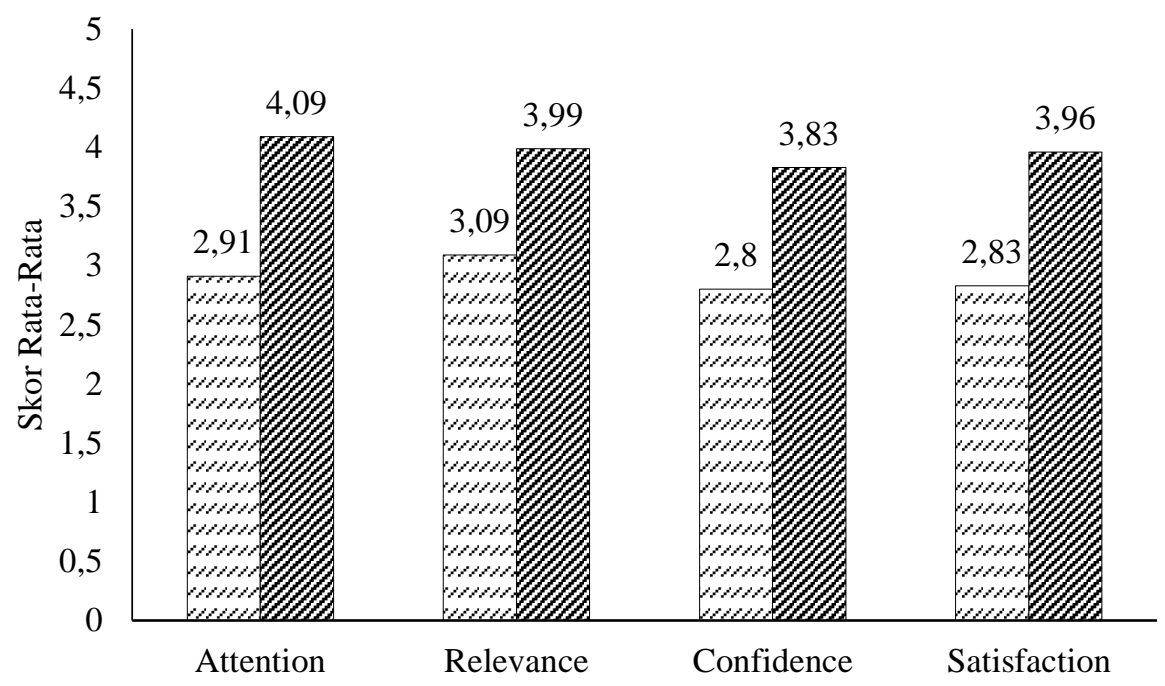

\Skr Sebelum penggunaan MGLP $\square$ Skor Setelah penggunaan MGLP

Gambar 8. Diagram perbandingan skor motivasi

Berdasarkan Gambar 8, peningkatan skor motivasi peserta didik dapat diketahui bahwa produk mobile game memberikan pengaruh yang cukup besar terhadap motivasi peserta didik baik dari segi attention, relevance, confidence ataupun satisfaction.

Peningkatan motivasi yang paling besar berada pada kategori attention. Peningkatan ini terjadi karena peserta didik tertarik belajar menggunakan media mobile game, sebab media ini memberikan angin segar untuk mengatasi kejenuhan mereka dalam mengerjakan tugas daring dirumah selama pandemi berlangsung. Kejenuhan melanda karena sebelum pandemi terjadi peserta didik terbiasa melakukan kegiatan pembelajaran kimia yang dikemas dengan kegiatan game berkelompok dan menggunakan beberapa aplikasi pembelajaran seperti kahoot! secara langsung.

Peningkatan terbesar kedua berada pada kategori satisfaction yang dirasakan oleh peserta didik sebab dapat belajar dan memenangkan game di setiap levelnya. Peningkatan terbesar ketiga berada pada kategori confidence. Peserta didik meyakini mampu belajar dengan baik menggunakan media ini. Peningkatan juga terjadi pada kategori relevance, dimana peserta didik memberikan tanggapan positif pada setiap pertanyaan yang mengacu pada kategori relevance.

Hasil penelitian ini relevan dengan hasil penelitian telah dilakukan oleh Cahyana (2017) yaitu pengembangan mengenai media mobile game based learning (MGBL) untuk mengetahui efek dari penggunaan mobile game guna meningkatkan hasil belajar siswa terkait dengan kemandirian belajar siswa dalam materi laju reaksi. Hasilnya media MGBL terkategori layak, praktis, menyenangkan, menarik dan dapat digunakan dimana saja serta sesuai dengan fasilitas yang dimiliki peserta didik.

Hasil penelitian produk ini juga relevan dengan penelitian yang telah dilakukan oleh Huang, Chang \& Wu (2017). Huang, Chang \& Wu melakukan uji penggunaan mobile app MGBL pada mahasiswa dengan berbagai gender, berbagai fakultas dan dari beberapa universitas di Taiwan Utara. Hasil penelitiannya adalah terjadi peningkatan antara nilai pretest dan juga posttest yang menunjukkan hasil belajar peserta didik yang positif setelah penggunaan mobile app MGBL.

Hasil penelitian pengembangan mobile game ini juga sejalan dengan hasil penelitian yang telah dilakukan oleh Lay dan Osman(2018)). Lay dan Osman melakukan penelitian untuk mengahui efek penggunaan Digital Games (MyKimDG) pada 138 peserta didik tingkat SMP di Malaysia. Temuan yang didapatkan oleh Lay dan Osman yaitu penggunaan Digital Games (MyKimDG) dapat meningkatkan motivasi belajar belajar sambil meningkatkan prestasi akademik dan keterampilan abad ke-21 (2018). 


\section{Jurnal Inovasi Pendidikan IPA, 7 (1), 2021 - 104}

Sri Yosimayasari, Hartono, Syarifuddin

Mobile game untuk pembelajaran pada materi larutan penyangga dapat meningkatkan hasil belajar peserta didik karena dapat menjadi sumber belajar yang menarik dan menyenangkan dalam mempelajari materi larutan penyangga. Materi yang disajikan dalam bentuk permainan dapat menarik perhatian peserta didik untuk belajar. Ringkasan, video animasi dan tutorial untuk menjawab pertanyaan disajikan dalam materi membuat mobile game ini relevan untuk mencapai tujuan pembelajaran. Penggunaan mobile game dapat meningkatkan rasa percaya diri peserta didik dalam belajar, membuat peserta didik berani mengambil keputusan dan berpikir kreatif dalam menyelesaikan game. Kemudian peserta didik mendapatkan kepuasan ketika memenangkan permainan tersebut. Hal ini dapat membuat peserta didik termotivasi untuk mempelajari materi kimia.

\section{SIMPULAN}

Mobile game pembelajaran materi larutan penyangga telah berhasil dikembangkan dan telah diuji validitas, kepraktisannya serta dapat meningkatkan hasil belajar dan skor motivasi peserta didik. mobile game untuk pembelajaran materi larutan penyangga dapat berkontribusi menjadi media pembelajaran yang menarik dan menyenangkan bagi peserta didik. Media ini dapat diakses dengan komputer ataupun smartphone di mana saja dan kapan saja sehingga peserta didik dapat mengulang pelajaran kapan pun mereka butuhkan.

\section{DAFTAR PUSTAKA}

Andromeda, Bahrizal, \& Ardina, Z. (2016). Efektifitas kegiatan praktikum terintegrasi dalam pembelajaran pada materi kesetimbangan kimia kelas XI SMA/MA. Eksakta, 1(17), 45-51. https://doi.org/10.1017/CBO9781107415324.004

Ayu, I., Susanti, L. . R., \& Wiyono, K. (2019). Pengembangan multimedia interaktif berbasis saintifik dalam mata pelajaran kimia materi laju redoks di kelas X. Jurnal Inovasi Pendidikan, 9(2), $57-$ 67.

Cahyana, U., Paristiowati, M., Savitri, D. A., \& Hasyrin, S. N. (2017). Developing and application of mobile game based learning (M-GBL) for high school students performance in chemistry. Eurasia Journal of Mathematics, Science and Technology Education, 13(10), 7037-7047. https://doi.org/10.12973/ejmste/78728

Chang, C. C., Liang, C., Chou, P. N., \& Lin, G. Y. (2017). Is game-based learning better in flow experience and various types of cognitive load than non-game-based learning? Perspective from multimedia and media richness. Computers in Human Behavior, 71, 218-227. https://doi.org/10.1016/j.chb.2017.01.031

Herliandry, L. D., Nurhasanah, N., Suban, M. E., \& Kuswanto, H. (2020). Pembelajaran pada masa pandemi covid-19. JTP - Jurnal Teknologi Pendidikan, 22(1), 65-70. https://doi.org/10.21009/jtp.v22i1.15286

Huang, Y. L., Chang, D. F., \& Wu, B. (2017). Mobile game-based learning with a Mobile app: Motivational effects and learning performance. Journal of Advanced Computational Intelligence and Intelligent Informatics, 21(6), 963-970.. https://doi.org/10.20965/jaciii.2017.p0963

Huizenga, J., Admiraal, W., Akkerman, S., \& Ten Dam, G. (2009). Mobile game-based learning in secondary education: engagement, motivation and learning in a mobile city game: Original article. Journal of Computer Assisted Learning, 25(4), 332-344. https://doi.org/10.1111/j.13652729.2009.00316.x

Huizenga, Jantina, Admiraal, W., Dam, G. ten, \& Voogt, J. (2019). Mobile game-based learning in secondary education: Students' immersion, game activities, team performance and learning outcomes. Computers in Human Behavior. https://doi.org/10.1016/j.chb.2019.05.020

Jones, O. A., Spichkova, M., \& Spencer, M. J. (2018). Chirality-2: Development of a multilevel mobile gaming app to support the teaching of introductory undergraduate-level organic chemistry. $\begin{array}{llllll}\text { Journal of Chemical Education } & 2018 \quad 95 & \text { (7), } & \text { 1216-1220 }\end{array}$ https://doi.org/10.1021/acs.jchemed.7b00856

Keller, J. M. (2010). Motivational Design for Learning and Performance The ARCS Model Approach. New York: Springer. 


\section{Jurnal Inovasi Pendidikan IPA, 7 (1), 2021 - 105}

Sri Yosimayasari, Hartono, Syarifuddin

Kousa, P., Kavonius, R., \& Aksela, M. (2018). Low-achieving students' attitudes towards learning chemistry and chemistry teaching methods. Chemistry Education Research and Practice, 19(2), 431-441. https://doi.org/10.1039/c7rp00226b

Lay, A. N., \& Osman, K. (2018). Developing 21st century chemistry learning through designing digital games. Journal of Education in Science Environment And Health, 4(1), 81-92.. https://doi.org/10.21891/jeseh.387499

Lin, M. H., \& Chen, H. G. (2017). A study of the effects of digital learning on learning motivation and learning outcome. Eurasia Journal of Mathematics, Science and Technology Education, 13(7), 3553-3564. https://doi.org/10.12973/eurasia.2017.00744a

Nugraha, I., Athfyanti, N. N., \& Prabawa, H. W. (2020). The development of computer-assisted instruction game on mirror reflection concepts for junior high school students. Jurnal Inovasi Pendidikan IPA, 6(1), 1-10. https://doi.org/10.21831/jipi.v6i1.28927

Onyema, E. M., Eucheria, N. C., Obafemi, F. A., Sen, S., Atonye, F. G., Sharma, A., \& Alsayed, A. O. (2020). Impact of Coronavirus pandemic on education. Journal of Education and Practice, 11(13), 108-121. https://doi.org/10.7176/jep/11-13-12

Perini, S., Luglietti, R., Margoudi, M., Oliveira, M., \& Taisch, M. (2018). Computers in Industry Learning and motivational effects of digital game-based learning ( DGBL ) for manufacturing education - The Life Cycle Assessment ( LCA ) game. Computers in Industry, 102, 40-49. https://doi.org/10.1016/j.compind.2018.08.005

Raja, R., \& Nagasubramani, P. C. (2018). Impact of Modern Technology. Journal of Applied and Advanced Research, 3, 33-35. https://doi.org/10.4324/9780203168899_chapter_10

Ratnasari, S., \& Setiawan, W. (2018). Analisis kesulitan belajar siswa pada materi larutan penyangga. Journal on Education, 1(2), 473-479.

Ristiyani, E., \& Bahriah, E. S. (2016). Analisis kesulitan belajar kimia siswa di SMAN X Kota Tangerang Selatan. Jurnal Penelitian Dan Pembelajaran IPA, 2(1), 18. https://doi.org/10.30870/jppi.v2i1.431

Saputri, A., Sukirno, S., Kurniawan, H., \& Probowasito, T. (2020). Developing Android Game-Based Learning Media "Go Accounting" in Accounting Learning. Indonesian Journal on Learning and Advanced Education (IJOLAE), 2(2), 91-99. https://doi.org/10.23917/ijolae.v2i2.9998

Setiaji, B., \& Dinata, P. A. C. (2020). Analisis kesiapan mahasiswa jurusan pendidikan fisika menggunakan e-learning dalam situasi pandemi Covid-19. Jurnal Inovasi Pendidikan IPA, 6(1), 59-70. https://doi.org/10.21831/jipi.v6i1.31562

Setiawan, A., Kusumo, E., Kasmui, K., \& Rahayu, S. (2019). Analisis Miskonsepsi Materi Larutan Penyangga Dalam Pembelajaran Berbasis Masalah Berbantuan Media Interaktif. Jurnal Inovasi Pendidikan Kimia, 13(2), 2383-2394. https://doi.org/10.15294/jipk.v13i2.15267

Srisawasdi, N., \& Panjaburee, P. (2019). Implementation of Game-transformed Inquiry-based Learning to Promote the Understanding of and Motivation to Learn Chemistry. Journal of Science Education and Technology, 28(2), 152-164. https://doi.org/10.1007/s10956-018-9754-0

$\mathrm{Su}$, C.-H., \& Cheng, C.-H. (2013). A Mobile Game-based Insect Learning System for Improving the Learning Achievements. Procedia - Social and Behavioral Sciences, 103, 42-50. https://doi.org/10.1016/j.sbspro.2013.10.305

Su, C. H., \& Cheng, C. H. (2015). A mobile gamification learning system for improving the learning motivation and achievements. Journal of Computer Assisted Learning, 31(3), 268-286. https://doi.org/10.1111/jcal.12088

Treagust, D., Nieswandt, M., \& Duit, R. (2018). Sources of students difficulties in learning Chemistry. Educación Química, 11(2), 228. https://doi.org/10.22201/fq.18708404e.2000.2.66458

Wang, L., Wang, X., Ju, Q., Li, Q., Li, M., \& Zhang, W. (2011). Game-based mobile learning system for campus on android platform. In International Conference on Technologies for E-Learning and Digital Entertainment. Springer, Berlin, Heidelberg. 55-62. https://doi.org/10.1007/978-3642-23456-9_12 